\title{
Hybrid Vigour? Genes, Genomics, and History
}

\author{
ROBERTA BIVINS ${ }^{1}$
}

\begin{abstract}
Is the gene 'special' for historians? What effects, if any, has the notion of the 'gene' had on our understanding of history? Certainly, there is a widespread public and professional perception that genetics and history are or should be in dialogue with each other in some way. But historians and geneticists view history and genetics very differently - and assume very different relationships between them. And public perceptions of genes, genetics, genomics, and indeed the nature and meanings of 'history' differ yet again. Here, in looking at the meaning, and the implications - the significance - of the gene (and its corollary scientific disciplines and approaches) specifically to historians, I will focus on two aspects of the discourse. First, I will examine the ways in which historians have thus far approached genes and genetics, and the impact such studies have had on the field. There is considerable overlap between the subject matter of genetics/genomics and many of the most widely used analytic categories of contemporary historiography - race, gender, sexuality, ethnicity, (dis)ability, among others. Yet the impact of genetics and genomics on society has been studied principally by anthropologists, sociologists and ethicists. ${ }^{2}$ Only two historical sub-disciplines have engaged with the rise of genetics to any significant degree: the histories of science and of medicine. What does this indicate or suggest? Second, I will explore the impact of the 'gene' and genetic understandings (of, for example, the body, health, disease, identity, the family, and evolution) on public conceptions of history itself.
\end{abstract}

\section{Decoding genetics: Historical approaches to the gene}

"I confess that from my experience as both an historian and someone who writes a great deal about current work in genetics, I am sceptical, I would even say biased, about claims of a genetic basis for any specific social behaviors." 3 So wrote the renowned historian of biology, Garland E. Allen in 1997. If genetics cannot explain even the 'social behaviours' of individuals, then clearly the gene has little to say about history. And Allen's scepticism about the claims made for genetics as an efficient cause or an explanatory system is widely shared by scholars in history, as well as in anthropology, sociology, science studies, and indeed the biological and medical sciences. But historians, particularly of science and medicine, are more than sceptical of the claims of genetic determinists: many are deeply ambivalent or openly apprehensive about what has been called the 'geneticization' of society. Historical studies of genetics reflect - and explain - their unease.

Historians have explored the gene both through studies of its scientific emergence, ${ }^{4}$ and through explorations of societal (and economic, and political, and cultural) responses to genetic claims, assumptions, and models of human heredity. ${ }^{5}$ Perhaps most disturbingly, historians have examined eugenics movements of the $20^{\text {th }}$ century, 
including the role of eugenic thinking in the Holocaust, in forced sterilization campaigns, and in enabling the other tragic outcomes of negative eugenics programmes. ${ }^{6}$ Eugenics, whether positive or negative, relied on assumptions that social traits - for instance, intelligence, industriousness, honesty, but also stupidity, laziness, and criminality - as well as physical ones were biologically inherited, and governed by genes. The commonsense of their day, these assumptions shaped the research designed to test them, and the interpretation of the data produced by those trials. Experiments constructed under these circumstances 'naturally' validated existing beliefs about both marginalized and privileged groups - and the evidence they produced was readily accepted as objective despite its poor quality. It is therefore unsurprising that historians like Garland Allen and Daniel Kevles are suspicious of contemporary scientists' claims to have found the genes for, say, homosexuality, or criminal violence, and fear that eugenic thought continues to underpin genetic science and genetic medicine. ${ }^{7}$ Simply put, historical comparisons suggest ominous similarities between these claims and those of their eugenic predecessors.

Other historical approaches have included the study of the gene as a $20^{\text {th }}$ century marker of 'biological determinism' (tainted in historical terms by its use in sociobiology, where 'biology' became 'destiny' in ways profoundly limiting for women, non-whites, and other marginalized groups); and related study of the ways in which genetics could facilitate the construction of a normative biology. ${ }^{8} \mathrm{Via}$ biography and autobiography, the history of genetics has also yielded exemplary accounts of gender bias in modern science. ${ }^{9}$ All in all, existing historical scholarship on the gene and genetics leaves little ground for optimism about the effects of our current cultural fascination with hereditarian, geneticized models of human culture and human history. The idea that our capabilities, our futures, even our souls are encoded in our genes, has historically proven a dangerous one; what risks then are likely to lie in seeking to understand ourselves and our pasts through our genes?

In my own historical field, the history of medicine, the impact of the gene and the genetic trope on medical research and practice is clearly visible, if as yet relatively unexplored - but the influence of genetic understandings of social, cultural and historical phenomena extends far more widely. As an example to illustrate the problem, consider the congested historical intersection between ideas of race and ideas of biological heredity. Jenny Reardon, working in the field of science and technology studies, has recently demonstrated (coincidentally displaying the traction historians could gain by actively engaging with the anthropological and science studies literatures), the polysemic flexibility and consequent durability of the concept and category 'race' within the scientific disciplines that have focused on heredity, and thus genetics. ${ }^{10}$ These traits make it extremely difficult to pin down, moment by historical moment, the meaning of race to scientists and within the scientific literatures. As the science of genetics (and subsequently genomics) gained broader and wider explanatory powers in relation to human variation, 'race' as an explanatory model could disappear linguistically, while persisting intellectually: biological and medical use of 'race' as a category of analysis went, as it were, underground, reinscribed in politically neutral terminology. Thus scientists and medical researchers could retain the analytical power of 'race' without the taint of racism. Many prominent post-war scientists explicitly denied biological 'race'. In severing the direct 
connection between the life sciences and racial thought, they also disrupted historical analyses that have been heavily dependent on the language of science, rather than its less accessible and historically documented practices.

This neat solution to the problem of 'race' for scientists was pioneered in the $1950 \mathrm{~s} .{ }^{11}$ Today, it persists. On one hand, clinical and research geneticists argue vociferously that self-identified race is only a 'weak surrogate' for a host of more complicated factors in morbidity. ${ }^{12}$ On the other, popular, commercial, and indeed some public health models of disease causation often present a far stronger programme, in which biological race determines susceptibility to particular diseases. Even geneticists adamant that 'race' is at best a proxy for authentic sources and markers of genetic difference make assumptions about the (biological and material) nature of those hypothetical authentic signs:

On the nongenetic side ... race carries with it certain social, cultural, educational and economic variables, all of which can influence disease risk. On the genetic side ... race is an imperfect surrogate for ancestral geographic origin, which in turn is a surrogate for genetic variation across an individual's genome... Considered in this context, it is apparent why self-identified race or ethnicity might be correlated with health status, through genetic or nongenetic surrogate relationships or a combination of the two. It is also evident that a true understanding of disease risk requires us to go well beyond these weak and imperfect proxy relationships. And if we are not satisfied with the use of imperfect surrogates in trying to understand hereditary causes, then we should not be satisfied with them as measures of environmental causation either. ${ }^{13}$

Collins, the science-trained commentator here, makes several key points. He identifies the flaws in current exclusively genetic models of race and race-linked morbidity, and states that they must be addressed - but note his conservatism, and application of the scientific methodology to 'environmental' (in other words, social) causation as well: "if we are not satisfied with the use of imperfect surrogates in trying to understand hereditary causes, then we should not be satisfied with them as measures of environmental causation either." History can tell us much about the implications of this kind of gene-thinking, with its stress on absolute certainty and one-to-one correlations of cause and effect. Epidemiological data necessarily often document proxy relationships, and draw attention to indirect, but nonetheless persuasive and relevant links between substances, behaviours and morbidities. Think for example of the long-contested status of the link between smoking and lung cancer. ${ }^{14}$ If only 'perfect' data and direct biological links are to be used in health policy making, the public can expect little protection or advice in health matters in the short- or mediumterm.

Collins also cautions: "If only genetic factors are considered, only genetic factors will be discovered." Historically, the dangers of this approach are all too obvious, as the cases of sickle cell anaemia and thalassaemia illustrate. Sickle cell anaemia (SCA) was first identified as a specific condition in 1910, by Chicago physician James Herrick. ${ }^{15}$ As a rare condition prevalent only in underprivileged minority populations, 
sickle cell anaemia triggered little clinical or biological interest. By the 1930s, smallscale studies identified the condition as genetically linked, and better defined its pathology, including distinctions between sickle cell disease (SCD) and sickle cell trait (SCT) ${ }^{16}$ By this point, the trend of identifying the disease not by its symptoms, but by the cellular phenomenon of 'sickling' was already established, as was a complete identification of the disease with an 'African' origin. ${ }^{17}$ Stigmatized in the US as a sign of African-American 'racial degeneration', the presence of SCA in a family was taken as irrefutable evidence of 'Negro blood' through the $1950 \mathrm{~s} .{ }^{18}$ Even - perhaps especially - after the specific genetic point mutation that produces SCT/SCA had been identified, racialized stigma remained. "What steps are being taken", wrote one British Member of Parliament (well-known for his racist views), "to warn the public as a preventive measure that the debilitating genetic disease known as sickle cell anaemia, not present in the indigenous population of Great Britain, can be inherited by the offspring of racially-mixed unions?"19 The same MP sought the segregation of the national blood banks. Only in the 1970s did more nuanced approaches to SCA and other conditions associated with (but not limited to) specific ethnic groups become the norm. ${ }^{20}$ Today, we are at risk of slipping backward, of returning to models in which the presence or absence of the genetic mutations associated with sickle cell anaemia or thalassaemia determines 'race' or ethnicity, trumping family history, self-identification, or pluralist ideas of individual heritage and selfhood.

And yet the study of the history of genetics has done much for the histories of science and medicine. For example, historians of science concerned with gender (most influentially Evelyn Fox Keller and Donna Haraway) have used molecular genetics and genomics as sites at which to explore the impact of gender on scientific thought, programmes of research, and paradigm-formation. Their work substantially enhanced the credibility of gender as a force in the development (and tool for the exploration) of the scientific professions, and the content of the sciences themselves. In part through this work on the metaphors and constitutive imagery in genetics and genomics, the language of science has been recognized as being more than merely didactic. Rather, it forms and reveals the intellectual structures through and within which scientists conceive their experimental and disciplinary programmes. ${ }^{21}$ History may have yet more to gain through tackling 'geneticization' head on; certainly, medical anthropology and medical sociology have captured new audiences - particularly in relation to health and science policy - through their direct engagement with the impact of genetics and genomics on lay attitudes towards health, risk, and identity. It seems likely that the discipline of history stands to lose at least some of the ground it has gained in terms of inclusivity and accessibility - largely through the growth of social history - if we ignore the impact of genetics on popular social and cultural understandings of history and the historical.

\section{History through a genetic lens: Genes, genomes, geneticists and the human past}

If the media are to be believed, there is a new kind of history out there, one written and embedded in the human body itself, and just waiting to be read by genetic and genomic scientists. The headline of a 2005 article in the respected UK newspaper The Guardian was blunt: "All of human history can be written with four letters". 22 The 
body of the article itself reveals the tension inherent in this view. On one hand, it presents DNA as a historical text that "reveals a lot about human evolution, and some family secrets, too." But only a sentence or two later, the reporter/protagonist describes the "piece of paper" which seemingly reveals all: "Among the multicoloured lines, the computer-generated graphs and the maps was an innocuous string of letters, beginning, GCTTCTCGCG." This is hardly the transparent window onto the past that one might have expected from the breathless narrative that preceded it.

Other accounts, leaning heavily on the traditions of sociobiology, ponder the history of human survival. Under the headline "Starch 'fuel of human evolution", a BBC News story recites a new scientific claim: "Man's ability to digest starchy foods like the potato may explain our success on the planet, genetic work suggests." ${ }^{, 2}$ Publicists, like journalists, make much of the power of this new discipline (unlike history based on documents, oral traditions, or even material culture or archaeological finds) to do away with 'prehistory' and the 'prehistoric'. The publishers of one recent book confidently asserted:

Historians relying on written records can tell us nothing about the 99.9 per cent of human evolution which preceded the invention of writing. It is the study of genetic variation, backed up by language and archaeology, which provides concrete evidence about the spread of cultural innovation, the movements of peoples ... the precise links between races. ${ }^{24}$

It is worth paying attention to this kind of ephemeral material, I would argue, if only because the use of such claims for mass marketing clearly illustrates the perceived appeal of a 'scientific', objective, and especially, a complete history.

Finally, this genetically inscribed past is presented as a corrective to the errors and biases of its more traditional analogue. Consider, for example the now famous role of genetics in re-writing the history of the third President of the United States of America, Thomas Jefferson. First, in the late 1990s, DNA testing confirmed the oral historical traditions of one branch of the Jefferson clan that they were the descendants of a child born to Jefferson and his slave, Sally Hemings. Unsurprisingly, given US racial politics, these claims had been fiercely denied by Jefferson's white descendants, and ignored as either tendentious or merely contentious by many historical texts and textbooks. It is a powerful indicator of the truth status granted by our society to 'genetic' knowledge that the DNA evidence silenced most (though not all) of the dissenting voices that had dominated debate for over 200 years. ${ }^{25}$ As if to confirm claims that human DNA is the 'archive' of this new history, the resources created to test claims of Jeffersonian paternity have now yielded new 'facts', including a putative Middle Eastern heritage for Jefferson himself:

While DNA tests carried out ten years ago famously showed the third US president Thomas Jefferson fathered a child with his slave, Sally Hemings, a new study has found his family comes from the Middle East. Experts at the University of Leicester found Jefferson's Y chromosome belongs to the rare 'K2' class, found in Egypt - and 
introduced to Britain thousands of years ago. ${ }^{26}$

Neither the original article, nor subsequent coverage supplied any interpretation of this new information about Jefferson. Whether this omission suggests that meaning is beyond the remit of genetic history, or that the meaning of the concrete evidence it supplies is or ought to be a truth self-evident is as yet unclear.

In each of these examples, we see the gene, or clusters of genes acting as a new kind of historical evidence, for a new kind of history, a 'history' with periodization often closer to that of geology than of social or political history. A rapidly growing body of (largely popular) work propounds this approach. Their titles are revealing: Mapping Human History: Genes, Race, and Our Common Origins; The Great Human Diasporas: The History of Diversity and Evolution; Genes, Memes and Human History: Darwinian Archaeology and Cultural Evolution. ${ }^{27}$ This history ignores or downplays the evidence and artifacts of culture in favour of molecular biological evidence. But just like the poorly or incompletely interpreted document, these apparently transparent physical artifacts can easily become meaningless, or even deceitful - artifacts in the biomedical, rather than the historical sense. Henry Louis Gates Jr, eminent Harvard scholar of African American literature, and an early enthusiast of the new history, was also an early victim of its flaws. ${ }^{28}$ In 2000 , having "come to the end of the paper trail" in his search for the African roots of his own family - in other words, having run out of conventional historical sources - Gates submitted his DNA for genetic testing, and was promised and then provided with definitive results pinpointing the geographical origins of his ancestors. So far, so good: geneticized history steps in to save the day when historical scholarship fails. Unfortunately, some time later, Gates took another DNA test, and was given different results. Instead of rejecting the approach that had left him with multiple identities, Gates founded a company to do it better, by incorporating more traditional historical methods. When interviewed by the Wall Street Journal on the subject, Gates agreed that the application of genetics to history was "problematic"; however, he ascribed the problems not to the nature of genetic evidence, but to "the reluctance of some companies to reveal the complexity of the results." 29

The names of the companies too are telling: DNA Tribes; African Ancestry; IdentityGenetics, Inc., and Gates' own AfricanDNA. Ideas of racial and ethnic identity are at the heart of this new industry. The companies are quite explicit both abut their target consumer groups, and the relationship between their services and 'history'. One corporate spokesperson argued: "For most African-Americans, there is no paper trail ... we make money, but we see this as a service to a people who have been cut off from their history and culture." ${ }^{30}$ Surely it behoves historians to examine this phenomenon and ask what analytic categories like 'race' and 'ethnicity' mean in their new context - and why they remain so attractive, when the very science that ostensibly underpins 'genetic history' claims that race does not exist as a biological entity.

One aspect that immediately strikes the historian's eye is the association between the 'Roots' phenomenon of the 1970s (particularly for African Americans) and the emergence of geneticized history. As David Chioni Moore pointed out in 1994, 
scholars across the humanities have yet to engage with the social and cultural impact of Alex Haley's novel Roots (and the 1970s television series based on it). ${ }^{31}$ As the actor Isaiah Washington noted of his own DNA ancestry test "I remember watching 'Roots' when I was young and it stuck with me. I always wanted to know where my ancestors came from before slavery, and here you have the science telling you." 32 Roots sent a generation of African Americans in search of their origins, with new hope that they might find an ancestor, biologically of the same substance, linking them directly and authentically to Africa. The controversies about plagiarism, fictionalized elements, and fabrications that soon surrounded Roots undermined that optimism and highlighted how difficult and dubious historical genealogy could be. Not only does genetic testing seem to offer an easier route to discovering a specific ancestral identity, but that origin is imbued with the same truth status that we as a society grant to scientifically created knowledge of the natural world in general: that of uncontestable fact.

Troy Duster, a sociologist who has studied this new marketplace of pasts, noted the impact that such tests can have on their recipients' identities: "People are making lifechanging decisions based on these tests and may not be aware of the limitations". ${ }^{33}$

So why have historians generally ignored this phenomenon in their explorations of the gene, genetics and genomics? Are we threatened by this new 'history from below' (or by the encroachments of science)? Or have genes just become the new germs - are we merely reproducing the scientific evangelism of our forebears, who sought a germ for every sickness just as passionately and unreasonably as we seek a gene for every trait? ${ }^{34}$ Part of the reason for historical indifference surely lies in the use to which geneticized history is currently being put. In 1942, the American ethnologists E. S. Craighill Handy and Elizabeth G. Handy tore their eyes away from Hawaiian culture long enough to wryly observe their own:

As a pleasant and harmless form of antiquarianism, the study of family history, biography, and the tracing of genealogy are tolerantly humoured but certainly not seriously honoured by historians and scientists. ... [F] amily records are considered of no importance to the larger world of scholarship and science unless related to the lives of distinguished persons.

The attitude they observed remains a part of historical culture (although thanks to social history, we have become considerably more enthusiastic about family records, and rather less exclusively concerned with 'distinguished persons'). But it is only a part of the answer. Like many professional historians, I am ambivalent about this newer, 'truer' - but also narrower - history. Because our society currently gives genetic information such a high truth status, we risk being blinded to persistent assumptions and prejudices if they are clothed in genetic terms. Anthropologists and sociologists are already exemplifying these problems in, for example, studies of the new reproductive technologies, and in medical and forensic genetics, but they are intimately linked, too, with the tools of 'genetic history'. As Duster points out,

There is a yet more ominous and troubling element of the reliance upon DNA analysis to determine who we are in terms of lineage, identity, and identification. The very technology that tells us what 
proportion of our ancestry can be linked, proportionately, to subSaharan Africa (ancestry-informative markers) is the same being offered to police stations around the [USA] to "predict" or "estimate" whether the DNA left at a crime scene belongs to a white or black person. This "ethnic estimation" using DNA relies on a social definition of the phenotype. ... With the demonstrable skew of the incarcerated population over the last few decades along social categories of race, African-Americans need to be particularly sensitive to the use of phenotype as the starting point for understanding genotype. ${ }^{36}$

Under these circumstances, it becomes the job of historians to point out the fact that we are repeating a pattern into which we have slipped before - and with no very positive outcome. Phrenological and anthropometric approaches to the modelling of race were also once the acme of modern science, and they have been retrospectively diagnosed as racist sciences; germ theory and eugenic sociobiology were applied to explain every human disease, to the great detriment of those treated with ineffective sera, or stigmatized as 'unfit to breed' (or 'lives not worth living').

Professional historians can also engage with this biological past creatively and productively. We need not simply dismiss it as old wine in new bottles. The gene has heightened the profile of what might called the historical mindset: the idea that the past is connected to the present, shapes it, and also can be revealed by it. While researching this piece, I meandered the far-flung tendrils of the web, looking for the different kinds of connections being made between the constructs 'gene' and 'history'. I was stunned to discover so prominent among them this idea that you could research your family history through genetic testing. But it casts light on a broader problem for the discipline. One difficulty professional historians have had in presenting satisfying representations of the past is not unlike the problem mathematicians - and indeed medical geneticists - have in explaining risk: just as they say that risk is probabilistic, and thus in individual cases uncertain, we say that history and historical outcomes are contingent and relative. Occam's Razor notwithstanding, knowledge-workers tend to enjoy complexity and to see it as signifying a richer and more accurate account of reality. But there is a break in the narrative flow of cause and effect when things get 'complicated'. The new genetic history bridges that chasm, in part by rooting itself so far in the past that the data have already been thoroughly winnowed. Thus another crucial element for historians to observe about the 'genetic turn' in history is that the ascendance of genetic explanations, particularly in relation to human traits and familial morbidity, is a return to narrative - albeit a narrative outside of time to all intents and purposes. Here, the past is not erased by progress, as is the ideal in many other sciences and scientific tropes - but it is encased in amber, reified, self-replicating, and crucially, linear. This is by no means a justification for writing poorer, simpler, artificially linear history. History is complicated, is contingent, is polysemic - we just have to render that complexity comprehensible and satisfying. 


\section{Acknowledgements}

I would like to thank the anonymous referees; the speakers and audience who attended the Cardiff University Centre for Applied Ethics 2007 workshop "What is special about the gene?"; and Mary Wren Bivins for their valuable comments on this piece.

\footnotetext{
${ }^{1}$ Cardiff School of History and Archaeology, Cardiff University, UK bivinsre@,cardiff.ac.uk

${ }^{2}$ In particular, those who work in the interdisciplinary nexus of science and technology studies. See for example, K. Finkler. 2000. Experiencing the New Genetics: Family and Kinship on the Medical Frontier. Philadelphia. University of Pennsylvania Press; S. Franklin. 2007. Dolly Mixtures: The Remaking of Genealogy. Durham, VA. Duke University Press; S. Franklin \& S. McKinnon, eds. 2001. Relative Values: Reconfiguring Kinship Study. Durham, VA. Duke University Press; H. L. Kaye. 1986. The Social Meaning of Modern Biology: From Social Darwinism to Sociobiology. London: Yale
} University Press.; J. Reardon. 2005. Race to the Finish: Identity and Governance in an Age of Genomics. Princeton: Princeton University Press; M. Strathern. 1992. Reproducing the Future: Essays on Anthropology, Kinship and the New Reproductive Technologies. New York. Routledge. I should note here also the highly pertinent contributions of geographer Catherine Nash. See C. Nash. Genetic kinship. Cultural Studies 2004; 18 (1): 1-33, for an excellent review of work specifically addressing 'genetic kinship', as well as a geographer's perspective on the new 'genetic genealogy' I discuss in section 2.

${ }^{3}$ G. E. Allen. The social and economic origins of genetic determinism: a case history if the American Eugenics Movement, 1900-1940 and its lessons for today. Genetica 1997; 99: 77-88 (p.78).

${ }^{4}$ Exemplars include L. Kay. 2000. Who Wrote the Book of Life? A History of the Genetic Code. Stanford, CA. Stanford University Press; J. Sapp. 1987. Beyond the Gene: Cytoplasmic Inheritance and the Struggle for Authority in Genetics. New York. Oxford University Press.

${ }^{5}$ For example, see P. J. Beurton, R. Falk \& H.-J. Rheinberger, eds. 2000. The Concept of the Gene in Development and Evolution: Historical and Epistemological Perspectives. Cambridge UK. Cambridge University Press; E. Fox Keller. 1992. Secrets of Life/Secrets of Death: Essays on Language, Gender and Science. New York \& London: Routledge. E. Fox Keller. 1995. Refiguring Life: Metaphors of Twentieth-century Biology. The Wellek Library Lecture Series at the University of California, Irvine. New York: Columbia University Press. Here I must also note a approach which has come to my attention too late for inclusion here. Hans-Jörg Rheinberger, Staffan Müller-Wille, and Christina Brandt have in recent years led a series of collaborative workshops aimed at defining 'A Cultural History of Heredity'. One volume of essays arising from this collaboration has now been published: S. Müller-Wille \& H.-J. Rheinberger, eds. 2007. Heredity Produced: At the Crossroads of Biology, Politics, and Culture, 1500-1870. Cambridge, MA. MIT Press. Further essays, more specifically related to the gene, are available online as preprint 343 at http://www.mpiwgberlin.mpg.de/en/research/preprints.html.

${ }^{6}$ That is, of attempts to improve the human race or breeding stock through eliminating those humans regarded as inferior, or as likely to produce inferior progeny. Negative eugenics is usually contrasted to positive eugenics, which strove to achieve the same ends - a better, healthier, and even happier human race - via encouraging 'superior' individuals to pair and produce many children. For an intriguing overview of the many different paths of eugenics in the US, see A. Minna Stern. 2005. Eugenic Nation: Faults and Frontiers of Better Breeding in Modern America. Berkeley, CA. University of California Press.

${ }^{7}$ Among many examples of this historical approach, see Allen, op. cit. note 3, and M.B. Adams, ed. 1990. The Wellborn Science: Eugenics in Germany, France, Brazil, and Russia. Oxford. Oxford University Press; D.J. Kevles. 1985. In the Name of Eugenics: Genetics and the Uses of Human Heredity. New York. Alfred A. Knopf; D.J. Kevles and L. Hood, eds. 1992. Code of Codes: Scientific and Social Issues in the Human Genome Project. Cambridge MA. Harvard University Press; R.N. Proctor. 1988. Racial hygiene: Medicine under the Nazis. Cambridge, MA. Harvard University Press; N.H. Rafter. 1997. Creating Born Criminals: Biological Theories of Crime and Eugenics. Urbana: 
University of Illinois Press; N. Leys Stepan. 1991. The Hour of Eugenics: Race, Gender and Nation in Latin America. Ithaca: Cornell University Press. P. Weindling. Modernising Eugenics. The Role of Foundations in International Population Studies. Minerva 2002; 167-179.

${ }^{8}$ For an overview and critique of biological determinism, see S.J. Gould. 1996. The Mismeasure of Man. New York: W. W. Norton; and G. Allen. The Roots of Biological Determinism. Journal of the History of Biology 1984; 17 (1): 141-145.

${ }^{9}$ See for example, E. Fox Keller. 1983. A Feeling for the Organism: The Life and Work of Barbara McClintock. San Francisco. Freeman; and compare, A. Sayre. 1975. Rosalind Franklin and DNA. New York. W.W. Norton \& Company with J.D. Watson, The Double Helix: A Personal Account of the Discovery of the Structure of DNA (Norton Critical Editions). New York. Norton. 1981 (originally published 1968).

${ }^{10}$ See Reardon, op.cit. note 2, esp. her second chapter 'Post World War II Expert Discourse on Race'. For an alternative perspective, see D.B. Paul. 1998. The Politics of Heredity: Essays on Eugenics, Biomedicine, and the Nature-Nurture Debate. Albany: State University of New York Press.

${ }^{11}$ Again, see Reardon, op. cit. note 2, who in chapter 2 offers valuable examples form the scientific literature.

${ }^{12}$ F.S Collins. What we do and don't know about 'race', 'ethnicity', genetics and health at the dawn of the genome era. Nature Genetics 2004; 36 Published online: 26 October 2004. Accessed 08/09/2007 at http://www.nature.com/ng/journal/v36/n11s/full/ng1436.html

${ }^{13}$ Ibid. Emphasis added.

${ }^{14}$ For a history, see A. Brandt. 2007. The Cigarette Century: The Rise, Fall, and Deadly Persistence of the Product That Defined America. New York. Basic Books; R. Kluger. 1996. Ashes to Ashes: America's Hundred-Year Cigarette War, The Public Health \& The Unabashed Triumph of Phillip Morris. Alfred A. Knopf.

${ }^{15}$ For a history of sickle-cell's biomedical discovery and elucidation, see C. Conley, 'Sickle-cell anaemia -- the first molecular disease' in M. Wintrobe, Blood, Pure and Eloquent: a story of discovery, or people and of ideas, New York, McGraw-Hill, 1980, pp. 319-37. See also K. Wailoo. A “disease sui generis": the origins of sickle cell anemia and the emergence of modern clinical research, 1904-1924. Bulletin of the History of Medicine 1991; 65: 185-208.

${ }^{16}$ Sickle cell anaemia is now recognized as the homozygous form of a balanced genetic polymorphism (pratically speaking, a trait that exists in multiple forms in a population, each form of which confers some selective advantage). People who are heterozygous for at the sickle cell locus have no symptoms of the disease, but can pass the trait to their children.

${ }^{17}$ The symptoms of sickle cell anaemia, as well as the anaemia itself and the painful crises, include capillary engorgement, leg ulcers, infections, thrombosis and a range of long-term sequelae including organ damage.

${ }^{18}$ K. Wailoo. 1997. Drawing Blood, Technology and Disease Identity in Twentieth Century America. Baltimore, MD. Johns Hopkins University Press: 134-161; M. Tapper. An "anthropathology" of the "American Negro": anthropology, genetics and the new racial science, 1940-1952. Social History of Medicine. 1997; 10: 263-89. This explanation, of course, fit well with US (and to a lesser degree UK) convictions about the dangers of miscegenation and racial mixing.

${ }^{19}$ The Minster of Health answered rather evasively, "None. Sickle cell anaemia can occur in children only where both parents carry the necessary mutant gene." See The National Archives (UK) MH159/121.

${ }^{20}$ See Wailoo, op. cit. note 15; K. Wailoo. 1997. Drawing Blood Technology and Disease Identity in Twentieth-Century America. Baltimore. The Johns Hopkins University Press; K. Wailoo. 2001. Dying in the City of the Blues: Sickle Cell Anemia and the Politics of Race and Health. Chapel Hill. University of North Carolina Press; M. Tapper. Interrogating Bodies: Medico-Racial Knowledge, Politics, and the Study of a Disease. Comparative Studies in Society and History 1995; 37: 76-93.

${ }^{21}$ See for examples, E.Fox Keller. 1992. Secrets of Life, Secrets of Death: Essays on Language, Gender, and Science. New York. Routledge; E.Fox Keller. 2000. The Century of the Gene. Cambridge, MA. Harvard University Press; D. araway.1997.Modest_Witness@Second_Millenium.Femaleman. copyright Meets_OncoMouse trademark: Feminism and Technoscience. London. Routledge; N. Stepan. Race and Gender: The Role of Analogy in Science. Isis 1986; 77: 261-277. E. Fox Keller. Gender and Science: Origin, History, and Politics. Osiris 1995 (2nd Series); 10: 26-38. For a brief case study of the role of gendered language in shaping experiments in early bacterial genetics (illustrating 
some of the strengths and the weaknesses of the linguistic turn in the history of science), see R. Bivins. Sex Cells: Gender and the Language of Bacterial Genetics. Journal for the History of Biology 2000; 33: 113-139.

${ }^{22}$ Alok Jha. All of human history can be written with four letters. The Guardian. April 28, 2005.

${ }^{23} \mathrm{http}: / /$ news.bbc.co.uk 10/09/07

${ }^{24}$ Cover text, L.L Cavalli-Sforza. 2001. Genes, Peoples and Languages. London. Penguin Press Science. Emphasis added.

${ }^{25}$ For a fuller account of this case, including documentary and biological evidence, chronology, and dissenting views, see J.E. Lewis \& P.S. Onuf, eds. 1999. Sally Hemings and Thomas Jefferson:

History, Memory and Civic Culture. Charlottesville: University Press of Virginia. This example was also disseminated to far wider audiences through the medium of a Public Broadcasting Service television series. See its homepage at http://www.pbs.org/wgbh/pages/frontline/shows/jefferson/ ${ }^{26}$ Anonymous. DNA reveals president's slave child. Rare Match. Metro (30/03/2007).

${ }^{27}$ L.L. Cavalli-Sforza. 1995. Great Human Diasporas: The History of Diversity and Evolution. New York. Addison-Wesley; S. Olson. 2002. Mapping Human History: Genes, Race, and Our Common Origins. New York. Houghton Mifflin; S. Shennan. 2002. Genes, Memes and Human History: Darwinian Archaeology and Cultural Evolution. London: Thames \& Hudson.

${ }^{28}$ R. Nixon. DNA Tests Find Branches But No Roots. New York Times (Business, November 25 2007).

${ }^{29}$ K.J. Winstein. Harvard's Gates Refines Genetic-Ancestry Searches for Blacks. Wall Street Journal (November 15,2007), D5. See also C. Elliott and P. Brodwin. Identity and genetic ancestry tracing. British Medical Journal 2002; 325 (7378), 1469-1471, which responds to the establishment of the first commercial genetic ancestry testing company; and Y. Ergorova \& T. Parfitt. 2006. Genetics, Mass Media and Identity: A Case Study of the Genetic Research on the Lemba and Bene Israel. London. Routledge.

${ }^{30}$ As quoted in Nixon, op. cit. note 18. See also Nash, op.cit. note 2.

${ }^{31}$ D. Chioni Moore. Routes. Transition 1994; 64: 4-21. See N.L. Arnez. From His Story to Our Story: A Review of "Roots". The Journal of Negro Education 1977; 46 (3): 367-372, for a contemporary perspective on the phenomenon.

${ }^{32}$ Nixon, op. cit. note 18 .

${ }^{33}$ Nixon, op. cit. note 18 .

${ }^{34}$ For examples of the public's enthusiastic embrace of the germ, see N. Tomes. 1998. The Gospel of Germs: Men, Women, and the Microbe in American Life. Cambridge, MA. Harvard University Press.

${ }^{35}$ E.S. Craighill Handy and E.G. Handy. Genealogy and Genetics. William and Mary Quarterly 1942; 22: 381-388 (p.386).

${ }^{36}$ T. Duster. Deep Roots and Tangled Branches. Longview Institute. Accessed 09/12/2008 at www.longviewinstitute.org/research/duster/deeproots 